\title{
Optimalisasi Operasi Mesin Cetak Pelet MKS-PLT15 Menggunakan Lagrange
}

\author{
Junas Haidi ${ }^{1}$, Yanolanda Suzantry $\mathrm{H}^{2}$, Adhadhi $\mathrm{K}^{3}$, A Sofwan $\mathrm{F}^{4}$ \\ Program Studi Teknik Elektro Universitas Bengkulu, Kota Bengkulu \\ Jl. Raya Kandang Limun Bengkulu 38371 \\ junas.haidi@unib.ac.id \\ ${ }^{2}$ yanolanda@unib.ac.id \\ 3 adhadhi.k@ac.id \\ ${ }^{4}$ sofwan.alqapdac.id
}

Intisari - Bengkulu dari Kabupaten Kaur sampai dengan Kabupaten Moko-Moko berbatasan langsung dengan laut Samudra Hindia. Sehingga banyak penduduk Bengkulu yang berprofesi nelayan dan petani. Tentunya dengan kekayaan alam yang berlimpah ada beberapa hasil ikan dan pertanian yang belum dimanfaatkan secara maksimal, misalnya anak ikan di Pulau Bai yang masih banyak dibuang dan dedak padi hasil penggilingan yang harganya sangat murah. Disisi lain ada permasalahan sangat besar yang dialami petani atau peternak di Provinsi Bengkulu yaitu harga pakan ternak ikan dan unggas sangat tinggi, sehingga membuat peternak ikan dan unggas tidak bisa bertahan karena tingginya biaya pakan. Untuk mengurangi biaya produksi pembuatan pelet maka dilakukan penelitian optimalisasi operasi mesin cetak pelet Tipe MKSPLT 15 ukuran dimensi 340 × $150 \times 325$ mm, daya yang digunakan sebesar 450 watt serta tegangan yang digunakan sebesar 220 v / 50 Hz. Penelitian yang dilakukan melihat operasi mesin di 25\%, 50\%, $75 \%$ dan $100 \%$, dari hasil penelitian yang telah dilakukan didapatkan hasil operasi mesin $25 \%$ biaya produksi pencetakan pelet $6 \mathrm{~mm} 0,00762 \mathrm{kwh} / \mathrm{kg}$ atau Rp. $11,021 / \mathrm{kg}$, operasi mesin $50 \%$ biaya produksi 0,009901 $\mathrm{kwh} / \mathrm{kg}$ atau $\mathrm{Rp} 14,3039 / \mathrm{kg}$ operasi mesin $75 \%$ biaya produksi pellet sebesar $0,01235 \mathrm{kwh} / \mathrm{kg}$ atau Rp. $17,842 / \mathrm{kg}$ sedangkan operasi mesin $100 \%$ biaya produksi pellet sebesar $0,01084 \mathrm{kwh} / \mathrm{kg}$ atau $\mathrm{Rp} 15,6605 / \mathrm{kg}$. sehingga dari penelitian yang dilakukan didapatkan pengoperasian mesin pellet MKS-PLT15 biaya produksi yang murah adalah di operasi mesin $0-50 \%$ dari kapasitas kemampuan mesin pellet beroperasi.

Kata kunci - Optimalisasi, Lagrange, Mesin Pelet, Tipe MKS-15, Biaya Operasi.

Abstract - Bengkulu Province from Kaur Regency to Moko-Moko Regency is directly adjacent to the Indian Ocean. So that many Bengkulu residents are fishermen and farmers. Of course, with abundant natural resources, there are some fish and agricultural products that have not been utilized optimally, for example, young fish on Bai Island which are still widely discarded and milled rice bran which is very cheap. On the other hand, there is a very big problem experienced by farmers or breeders in Bengkulu Province, namely the price of fish and poultry feed is very high, thus making fish and poultry farmers unable to survive because of the high cost of feed. To reduce the production cost of making pellets, a research was carried out on optimizing the operation of the pellet molding machine Type MKS-PLT 15 with dimensions of $340 \times 150 \times 325 \mathrm{~mm}$, the power used was 450 watts and the voltage used was $220 \mathrm{v} / 50 \mathrm{~Hz}$. The research carried out looked at the machine operation at $25 \%, 50 \%, 75 \%$ and $100 \%$, from the results of the research that had been carried out, it was found that the $25 \%$ machine operation cost of $6 \mathrm{~mm}$ pellet printing was $0.00762 \mathrm{kwh} / \mathrm{kg}$ or Rp. $11.021 / \mathrm{kg}$, machine operation $50 \%$ production cost $0.009901 \mathrm{kwh} / \mathrm{kg}$ or $\mathrm{Rp.} 14.3039 / \mathrm{kg}$ machine operation $75 \%$ pellet production cost $0.01235 \mathrm{kwh} / \mathrm{kg}$ or $\mathrm{Rp} .17 .842 / \mathrm{kg}$ while the machine operation is $100 \%$ pellet production cost of $0.01084 \mathrm{kwh} / \mathrm{kg}$ or Rp.15.6605/kg. so that from the research carried out, it was found that the operation of the MKS-PLT15 pellet machine, the low production cost, was in machine operation $0-50 \%$ of the capacity of the pellet machine's ability to operate.

Keywords - Optimization, Lagrange, Pellet Machine, Type MKS-15, Operating Cost. 


\section{PENDAHULUAN}

Industri pakan sebagai industri hulu memiliki peranan yang sangat penting dalam pengembangan industri peternakan. Industri yang bergerak dibidang pakan ternak di Indonesia bervariasi, mulai dari industri besar sampai industri kecil. Industri-industri tersebut mempunyai hasil produk berupa

pakan ternak dengan kualitas dan kuantitas yang berbeda. Kualitas pakan yang berbeda akan menyebabkan hasil produksi yang berbeda. Beberapa faktor yang berpengaruh terhadap kualitas bahan baku yaitu pengelolaan dan kondisi penyimpanan [1].

Pakan merupakan salah satu komponen yang sangat menunjang kegiatan usaha budidaya perikanan, sehingga pakan yang tersedia harus memadai dan memenuhi kebutuhan ikan. Pada budidaya ikan 60\%$70 \%$ biaya produksi digunakan untuk biaya pakan [2]. Peningkatan efisiensi pakan melalui pemenuhan kebutuhan nutrisi sangat dibutuhkan dalam rangka menekan biaya produksi. Di era globalisasi ini bahan pakan ikan yang semakin mahal mempengaruhi harga pakan pada umumnya. Banyak bahan pakan yang harus didapat dari impor. Oleh karena itu segi biaya pakan merupakan faktor yang paling tinggi pengeluarannya. Selain biaya pakan, kebutuhan nutrisi dari ikan harus diperhatikan. Ketersediaan pakan akan berpengaruh terhadap pertumbuhan dan kelangsungan hidup ikan yang dibudidayakan. Pakan yang diberikan pada ikan dinilai baik tidak hanya dari komponen penyusun pakan tersebut melainkan juga dari seberapa besar komponen yang terkandung dalam pakan mampu diserap dan dimanfaatkan oleh ikan dalam kehidupannya [3]. Dalam proses budidaya ikan khususnya pada kegiatan pembesaran, faktor yang terpenting adalah ketersediaan pakan dalam jumlah yang cukup, dan harus mengandung seluruh nutrient yang diperlukan, yakni karbohidrat, lemak, protein, mineral dan vitamin dalam jumlah yang cukup dan seimbang. Kondisi tersebut sangat dibutuhkan bagi usaha bidang budidaya perikanan [4].
Pellet yang baik adalah pellet yang memiliki index ketahanan (Pellet Durability Index) yang baik sehingga dalam proses penanganan dan transportasi pellet tidak mengalami kerusakan secara fisik, tetap kompak, kokoh dan tidak mudah rapuh [5]. [6] menyatakan bahwa standar spesifikasi Pellet Durability Index (PDI) minimum adalah $80 \%$. Daya tahan pelet dipengaruhi oleh komposisi kimiawi bahan yaitu lemak, pati, protein, serta serat [7]. Pellet Durability Index juga dapat dipengaruhi oleh ukuran partikel pelet. Makin kecil ukuran pelet maka semakin menunjang kekerasan dan ketahanan pelet yang dihasilkan, karena semakin banyak pati yang diubah oleh uap panas menjadi perekat maka dapat membantu proses perekatan partikel-partikel dalam bahan baku.

Mesin pencetak pelet merek Beje model UPTK 081B adalah mesin yang berfungsi untuk mencetak bahan pakan ikan menjadi bentuk pelet. Mesin ini secara umum terdiri dari motor penggerak, bagian pencetak, bagian pengumpan, dan bagian pengeluaran. Bagian pengumpan berfungsi untuk menampumg dan menyalurkan bahan yang akan dicetak. Bagian pencetak berfungsi sebagai tempat pencetakan yang dilengkapi piringan pencetak, roda ulir penekan dan pisau pemotong. Bahan yang masuk dalam ruang pencetak ditekan oleh roda ulir penekan berupa piring alas penekan. Mesin ini menggunakan motor diesel sebagai tenaga penggerak dengan daya $11 \mathrm{hp}$. Tetapi mesin ini masih memiliki kelemahan yaitu getaran dan suara mesin masih terasa kasar, aklerisasi masih terasa lambat, tenaga dan kekuatan lebih lambat, dan tidak cocok untuk beban yang terlalu banyak [8].

Penelitian sebelumnya dalam [9] tujuan dari proyek akhir ini adalah rancang bangun mesin pencetak pelet. Hasil rancang bangun mesin pencetak pelet, spesifikasi sebagai berikut menggunakan penggerak motor bakar bensin merek DAEZEN 6,5 Hp/3600 rpm, putaran mesin yang diturunkan dari motor bakar ke poros dan piringan pencetak menjadi $600 \mathrm{rpm}$, kapasitas mesin pencetak pelet ini adalah $25 \mathrm{Kg} / \mathrm{jam}$. Hasil pencetakan berbentuk seperti butiran kecil. 
Referensi [10] menunjukkan bahwa sebuah rancangan mesin pencetak pelet pakan ternak menggunakan motor listrik 1 HP 1400 Rpm dengan sistem transmisi pulley dan belt serta sistem penekan menggunakan roda gigi dan sistem hopper input menggunakan hopper berbentuk corong yang mempermudah proses memasukan bahan pelet. Hasil uji coba di dapatkan mesin mampu mencetak pelet dimater $8 \mathrm{~mm}$ dan panjang $15 \mathrm{~mm}$ dengan kapasitas $30 \mathrm{~kg} / \mathrm{jam}$.

Tingginya permintaan pakan ikan tidak dibarengi dengan harga ikan. Hal ini menyebabkan usaha tambak ikan yang dikelola sering mengalami kerugian dalam hal tenaga dan waktu. Kebanyakan Pengusaha tambak ikan belum mengetahui cara membuat pelet ikan secara mandiri. Hal ini disebabkan mahalnya harga mesin pelet ikan yang ada di pasaran. Dan petani belum mengetahui teknologi untuk pembuatan mesin pelet ikan. Dan Tujuan dari pembuatan tugas akhir adalah untuk melakukan rancang bangun mesin pencetak pelet tipe extruder. Dalam perancangan ulang ini menggunakan daya motor 4101Watt dengan putaran $1440 \mathrm{rpm}$, sedangkan diameter poros motor penggerak berukuran $25 \mathrm{~mm}$, dan diameter mesin pencetak pelet tipe extruder $80 \mathrm{~mm}$. Penggerak memakai sabuk $V$-belt tipe B sebanyak 1 buah, dengan jarak antara poros $600 \mathrm{~mm}$. Hasil akhir yang di capai dalam tugas akhir ini yaitu mesin pencetak pelet tipe extruder dengan kapasitas produksi maksimum $50 \mathrm{~kg} / \mathrm{jam}$. Dengan campuran bahan antara lain dedak, tepung kedelai, tepung jagung, tepung kanji, tepung ikan, ragi dan air. Diharapkan mesin pencetak pelet tipe extruder ini dapat dimanfaatkan oleh para peternak dan pembudidaya ikan sebagai teknologi tepat guna untuk meningkatkan hasil bidang peternakan dan perikanan, sehingga para petani tidak bergantung lagi pada persediaan pakan di pasaran, karena mereka dapat membuat pakan sendiri dengan harga bahan baku yang lebih murah [11].

Provinsi Bengkulu dari Kabupaten Kaur sampai dengan Kabupaten Moko-Moko berbatasan langsung dengan laut samudra hindia. Sehingga banyak penduduk Bengkulu yang berprofesi nelayan dan petani. Tentunya dengan kekayaan alam yang berlimpah ada beberapa hasil ikan dan pertanian yang belum dimanfaatkan secara maksimal, misalnya anak ikan di pulau bai yang masih banyak dibuang dan dedak padi hasil penggilingan yang harganya sangat murah. Disisi lain ada permasalahan sangat besar yang dialami petani atau peternak di Provinsi Bengkulu yaitu harga pakan ternak ikan dan unggas sangat tinggi, sehingga membuat peternak ikan dan unggas tidak bisa bertahan karena tingginya biaya pakan. Tentunya UNIB sebagai univeritas terbesar di Bengkulu dituntut untuk berdistribusi mengatasi permasalahan yang ada di wilayah Bengkulu. Maka perlu dibuat mesin pencetak pelet yang mudah dioperasikan oleh ma syarakat luas khususnya masyarakat di kota Bengkulu dengan tujuan mengetahui unjuk kerja dari mesin pencetak pelet sehingga menghasilkan nilai optimalisasi dari operasi mesin cetak pelet. Dari latar belakang di atas maka penelitian ini tentang Optimalisasi Operasi Mesin Cetak Pelet MKS-PLT 15 menggunakan lagrange.

\section{METODOLOGI}

\section{A. Persiapan bahan}

Untuk melihat karakteristik mesin pelet MKS-PLT15 dilakukan ujicoba pengoperasian mesin pelet bekerja dari beban no load sampai dengan full load. Adapun pelet yang digunaka adalah pelet pakan ikan apung yang dibuat oleh PT. CJ Cheiijedang Feed Semarang AT-3 kode produksi 1128519325 dengan kandungan protein $15 \%$.

\section{B. Peralatan pendukung}

Untuk melakukan pengujian karakteristik mesin pelet MKS-PLT15 adapun peralatan pendukung yang digunakan saat penelitian sebagai berikut:

1. Mesin pencetak pelet MKS-PLT15 kapasitas produksi 20kg perjam

2. Kompor listrik 800 watt satu unit.

\section{Metodologi penelitian yang dilakukan}

1) Persiapan bahan baku pelet.

Pada saat penelitian bahan pelet yang digunakan adalah pelet yang suda jadi dipasaran dengan kandungan protein $15 \%$ yang diproduksi oleh PT. CJ Cheiijedang 
Feed Semarang. Langkah yang dilakukan adalah mempersiapkan pelet yang sudah jadi sebanyak $50 \mathrm{~kg}$, pelet sebanyak $50 \mathrm{~kg}$ tersebut dibagi menjadi $5 \mathrm{~kg}, 10 \mathrm{~kg}, 15 \mathrm{~kg}$ dan $20 \mathrm{~kg}$, setelah selesai dilakukan pembagian berat pelet maka dilakukan penyiraman air panas kepelet agar pelet menjadi lembut dan bisa dihancurkan sampai rata. Setelah pelet menjadi halus dan siap untuk dicetak ulang dengan menggunakan mesin pelet MKSPLT15. Adapun gambar peleburan pelet dapat dilihat pada Gambar 1.

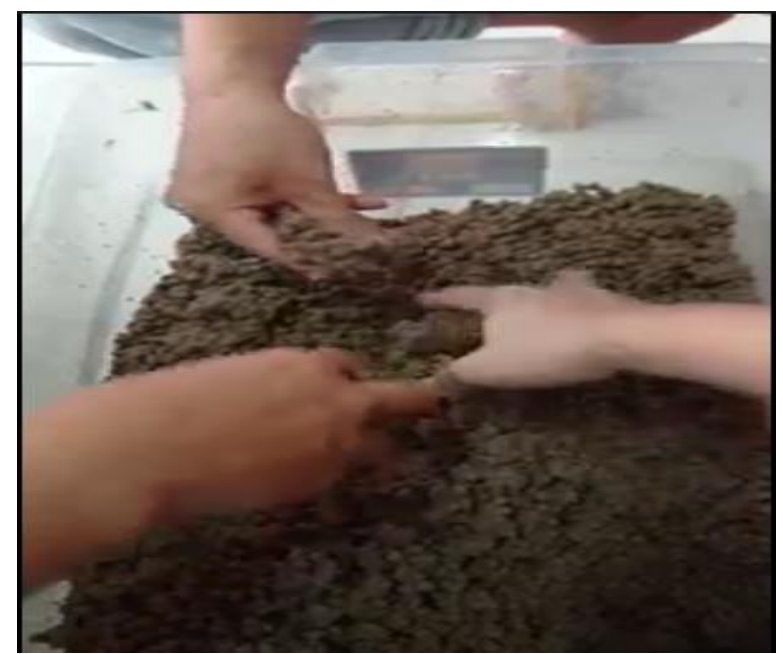

Gbr. 1 Peleburan Pelet

2) Pengambilan data pengujian mesin pelet MKS-PLT15

Setelah pelet suda siap dicetak kembali dengan menggunakan mesin MKS-PLT15, proses selanjutnya adalah mencetak pelet dengan ukuran $6 \mathrm{~mm}$ sebanyak $5 \mathrm{~kg}$. Pencetakan pelet dengan kapasitas $5 \mathrm{~kg}$ membutuhkan waktu selama 18 menit dengan total konsumsi energi listrik 38,148Wh dapat dilihat pada Grafik Gambar 2.

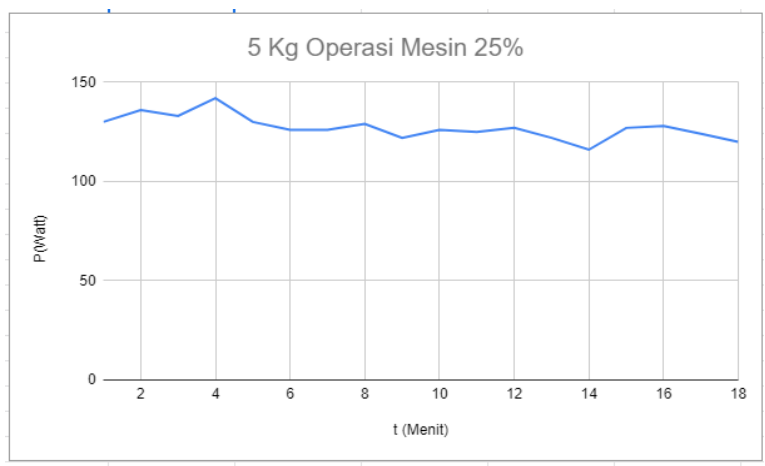

Gbr. 2 Perbandingan Operasi Mesin Pakan Terhadap Daya $(25 \%)$

Pencetakan pelet sebanyak $10 \mathrm{~kg}$ membutuhkan waktu selama 43 menit dengan konsumsi energi listrik sebesar 99,01Wh dapat dilihat pada Grafik Gambar 3.

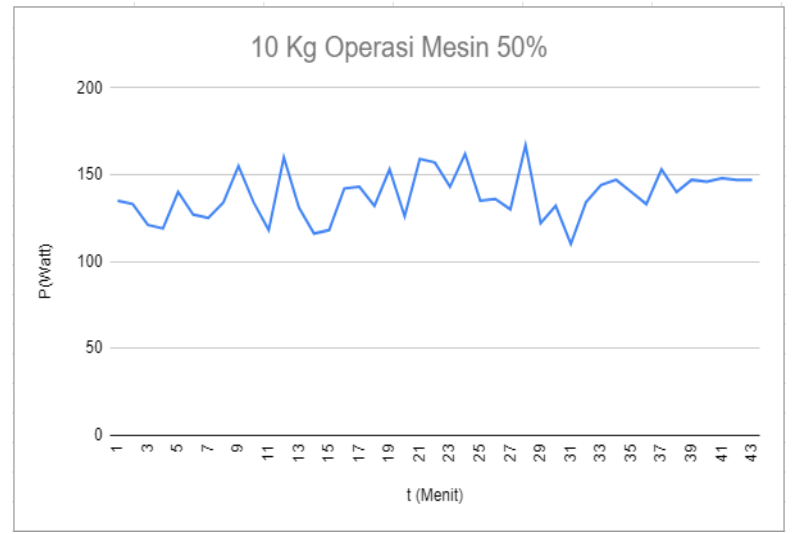

Gbr. 3 Perbandingan Operasi Mesin Pakan Terhadap Daya (50\% )

Pencetakan pelet sebanyak $15 \mathrm{~kg}$ selama 73 menit dengan konsumsi energi listrik sebesar $185,25 \mathrm{Wh}$ dapat dilihat pada Grafik Gambar 4.

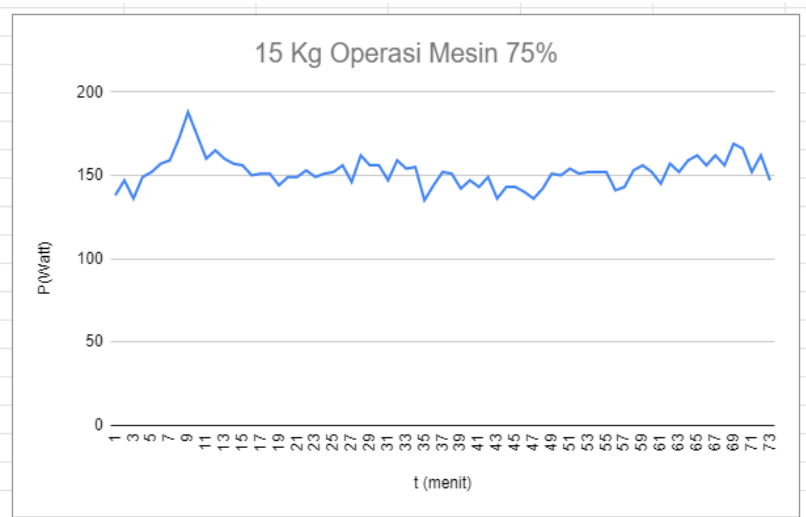

Gbr. 4 Perbandingan Operasi Mesin Pakan Terhadap Daya $(75 \%)$

Pencetakan pelet sebanyak 20kg dilakukan selama 85 menit dengan konsumsi energi listrik sebesar 216,816Wh dapat dilihat pada Grafik Gambar 5.

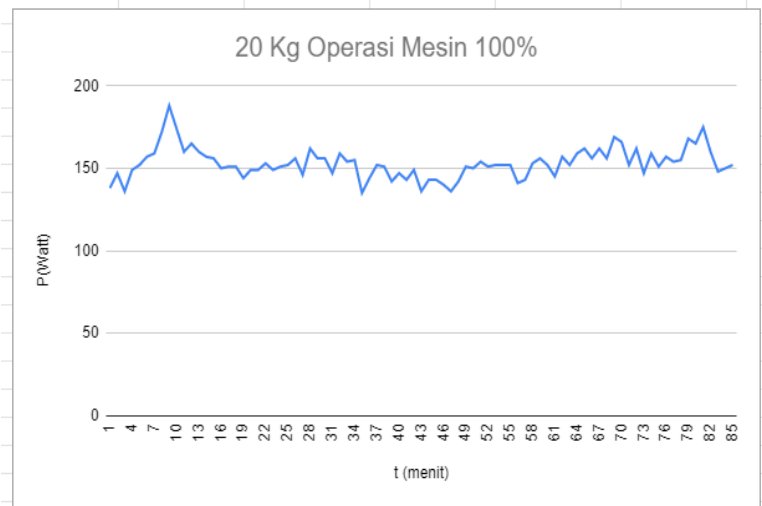

Gbr. 5 Perbandingan Operasi Mesin Pakan Terhadap Energi (100\%) 
Pengambilan data produksi pelet pada Gambar 2, Gambar 3, Gambar 4, dan Gambar 5 dilakukan sebanyak satu kali percobaa. Karakteristik grafik yang dihasilkan pada Gambar 2, Gambar 3, Gambar 4, dan Gambar 5 terjadi perbedaan, disebabkan pembebanan yang tidak sama setiap menitnya sehingga konsumsi daya listrik berbanding lurus dengan beban saat itu. Fluktuasinya grafik yang dihasilkan tidak berpengaruh terhadap total daya yang digunakan saat produksi kapasitas 25\%, 50\%, 75\%, dan 100\%. Karena semakin besar daya pada grafik, maka kecepatan produksi akan meningkat dan semakin rendah daya pada grafik maka kecepatan produksi akan melambat dan menyebabkan waktu produksi akan bertambah.

\section{HASIL DAN PEMBAHASAN}

\section{A. Analisis Tabel}

Dari percobaan yang telah dilakukan pada mesin cetak pelet MKS-PLT15 dengan pengoperasian kapasitas mesin pelet $25 \%$, $50 \%$, $75 \%$ dan $100 \%$. Sebelum didapat dari harga listrik PLN pada tanggal satu September 2021 sebesar Rp. 1444,70 per Kwh. Untuk kolom 6 pada tabel 1 hasil dari $\mathrm{Rp} / \mathrm{Kg}$ didapt dari rumus $\mathrm{KWh} / \mathrm{kg}$ x Rp. 1444,70/ KWh. Hasil yang didapat pada grafik Gambar 1 sampai Gambar 5 dapat disederhanakan pada Tabel 1 dibawah ini.

Tabel 1. Unjuk Kerja Pengujian Mesin Pelet

\begin{tabular}{|c|c|c|c|c|c|c|}
\hline $\begin{array}{c}\text { Opera } \\
\text { si } \\
\text { mesin } \\
(\%)\end{array}$ & $\begin{array}{c}\text { Produ } \\
\mathrm{ksi} \\
(\mathrm{kg})\end{array}$ & $\mathrm{Wh}$ & $\begin{array}{c}\mathrm{Wh} / \\
\mathrm{kg}\end{array}$ & $\begin{array}{c}\mathrm{kWh} / \mathrm{k} \\
\mathrm{g}\end{array}$ & $\mathrm{Rp} / \mathrm{kg}$ & $\mathrm{Rp}$ \\
\hline 25 & 5 & 48 & 29 & 629 & 21 & 1 \\
\hline & & 99,0 & 9,9 & 0,009 & 14,3 & 143, \\
50 & 10 & 1 & 01 & 901 & 039 & 039 \\
\hline & & 185, & 12, & 0,012 & 17,8 & 267, \\
75 & 15 & 25 & 35 & 35 & 420 & 63 \\
\hline & & 216, & 10, & 0,010 & 15,6 & 312, \\
100 & 20 & 816 & 84 & 84 & 605 & 05 \\
\hline
\end{tabular}

Dari Tabel 1 colom kedua dan colom kelima dapat dibuat polynomial tingkat 2 dengan menggunakan persamaan 1 dari perhitungan menggunakan persamaan 1 didapatkan persamaan polynomial tingkat dua menggunakan metode lagrange.

$$
\begin{aligned}
C=(-3,78 \times & \left.10^{-5}-\right) P^{2} \\
& +\left(1,19 \times 10^{-3}\right) P \\
& +2,43 \times 10^{-3}
\end{aligned}
$$

Dari persamaan (1) polynomial yang didapatkan pada $\mathrm{C}$ maka dibuat fungsi polynomial orde 1 .

$$
\lambda=\beta_{i}+2 \gamma_{i} \mathrm{P}_{i}
$$

$$
\lambda=2,42 \times 10^{-4} \mathrm{P}+7,16 \times 10^{-3}
$$

$$
\mathrm{P} i=\frac{\lambda-\beta_{i}}{2 \gamma_{i}}
$$

$$
\sum_{i=1}^{n} \frac{\lambda-\beta_{i}}{2 \gamma_{i}}=\mathrm{P}_{b e b a n}
$$

$$
\begin{gathered}
\lambda=\frac{\mathrm{P}_{\text {beban }}+\sum_{i=1}^{n} \frac{\beta_{i}}{2 \gamma_{i}}}{\sum_{i=1}^{n} \frac{1}{2 \gamma_{i}}} \\
\lambda=\frac{\mathrm{P}+\frac{\beta}{2 \gamma}}{\frac{1}{2 \gamma}}
\end{gathered}
$$

Dengan menggunakan persamaan 2 maka konsumsi daya listrik untuk memproduksi pelet dapat dilihat pada Tabel 2 dengan harga listrik Rp 1444,70/kWh. Dari Tabel 2 dapat dilihat bahwa pengoperasian mesin pelet MKS-PLT15 dengan biaya produksi penggunaan listrik terhemat saat produksi pelet sebanyak $1 \mathrm{~kg}$ sebesar $\mathrm{Rp} 10,69 / \mathrm{kg}$ sampai produksi pelet sebanyak $10 \mathrm{~kg}$ sebesar $\mathrm{Rp} 13,85 / \mathrm{kg}$. Konsumsi listrik pada saat mesin beroperasi diatas $50 \%$ biaya listrik untuk memproduksi pelet per kilogramnya adalah Rp14,17/kg samapi dengan Rp 17,30/kg. sehingga berdasarkan analisa dan perhitungan yang telah dilakukan maka direkomendasikan penggunaan mesin pelet beroperasi pada kapasitas kurang dari 50\% dari kapasitas maksimum kemampuan mesin bekerja. 
Tabel 2. Unjuk kerja mesin pelet menggunakan metode Lagrange

\begin{tabular}{|c|c|c|c|}
\hline $\begin{array}{c}\text { Beban } \\
\text { Produks } \\
\text { i (kg) }\end{array}$ & $\begin{array}{c}\text { Konsums } \\
\text { i Listrik } \\
(\mathrm{kWh} / \mathrm{kg})\end{array}$ & $\begin{array}{c}\text { Biaya } \\
\text { Konsumsi } \\
\text { Listrik } \\
(\mathrm{Rp} / \mathrm{kg})\end{array}$ & $\begin{array}{c}\text { Biaya } \\
\text { Konsums } \\
\text { i (Rp) }\end{array}$ \\
\hline 1 & $\begin{array}{c}0.007401 \\
0\end{array}$ & $\begin{array}{c}10.692224 \\
7\end{array}$ & $\begin{array}{c}10.69222 \\
5\end{array}$ \\
\hline 2 & $\begin{array}{c}0.007642 \\
0\end{array}$ & $\begin{array}{c}11.040397 \\
4\end{array}$ & $\begin{array}{c}22.08079 \\
5\end{array}$ \\
\hline 3 & $\begin{array}{c}0.007883 \\
0\end{array}$ & $\begin{array}{c}11.388570 \\
1\end{array}$ & 34.16571 \\
\hline 4 & $\begin{array}{c}0.008124 \\
0\end{array}$ & $\begin{array}{c}11.736742 \\
8\end{array}$ & $\begin{array}{c}46.94697 \\
1\end{array}$ \\
\hline 5 & $\begin{array}{c}0.008365 \\
0\end{array}$ & $\begin{array}{c}12.084915 \\
5\end{array}$ & $\begin{array}{c}60.42457 \\
8\end{array}$ \\
\hline 6 & $\begin{array}{c}0.008606 \\
0\end{array}$ & $\begin{array}{c}12.433088 \\
2\end{array}$ & $\begin{array}{c}74.59852 \\
9\end{array}$ \\
\hline 7 & $\begin{array}{c}0.008847 \\
0\end{array}$ & $\begin{array}{c}12.781260 \\
9\end{array}$ & $\begin{array}{c}89.46882 \\
6\end{array}$ \\
\hline 8 & $\begin{array}{c}0.009088 \\
0\end{array}$ & $\begin{array}{c}13.129433 \\
6\end{array}$ & $\begin{array}{c}105.0354 \\
7\end{array}$ \\
\hline 9 & $\begin{array}{c}0.009329 \\
0\end{array}$ & $\begin{array}{c}13.477606 \\
3\end{array}$ & $\begin{array}{c}121.2984 \\
6\end{array}$ \\
\hline 10 & $\begin{array}{c}0.009570 \\
0\end{array}$ & 13.825779 & $\begin{array}{c}138.2577 \\
9\end{array}$ \\
\hline 11 & $\begin{array}{c}0.009811 \\
0\end{array}$ & $\begin{array}{c}14.173951 \\
7\end{array}$ & $\begin{array}{c}155.9134 \\
7\end{array}$ \\
\hline 12 & $\begin{array}{c}0.010052 \\
0\end{array}$ & $\begin{array}{c}14.522124 \\
4\end{array}$ & $\begin{array}{c}174.2654 \\
9\end{array}$ \\
\hline 13 & $\begin{array}{c}0.010293 \\
0\end{array}$ & $\begin{array}{c}14.870297 \\
1\end{array}$ & $\begin{array}{c}193.3138 \\
6\end{array}$ \\
\hline 14 & $\begin{array}{c}0.010534 \\
0\end{array}$ & $\begin{array}{c}15.218469 \\
8\end{array}$ & $\begin{array}{c}213.0585 \\
8\end{array}$ \\
\hline 15 & $\begin{array}{c}0.010775 \\
0\end{array}$ & $\begin{array}{c}15.566642 \\
5\end{array}$ & $\begin{array}{c}233.4996 \\
4\end{array}$ \\
\hline 16 & $\begin{array}{c}0.011016 \\
0\end{array}$ & $\begin{array}{c}15.914815 \\
2\end{array}$ & $\begin{array}{c}254.6370 \\
4\end{array}$ \\
\hline 17 & $\begin{array}{c}0.011257 \\
0\end{array}$ & $\begin{array}{c}16.262987 \\
9\end{array}$ & $\begin{array}{c}276.4707 \\
9\end{array}$ \\
\hline 18 & $\begin{array}{c}0.011498 \\
0\end{array}$ & $\begin{array}{c}16.611160 \\
6\end{array}$ & $\begin{array}{c}299.0008 \\
9\end{array}$ \\
\hline 19 & $\begin{array}{c}0.011739 \\
0\end{array}$ & $\begin{array}{c}16.959333 \\
3\end{array}$ & $\begin{array}{c}322.2273 \\
3\end{array}$ \\
\hline 20 & $\begin{array}{c}0.011980 \\
0 \\
\end{array}$ & 17.307506 & $\begin{array}{c}346.1501 \\
2 \\
\end{array}$ \\
\hline
\end{tabular}

\section{KESIMPULAN}

Berdasarkan penelitian unjuk kerja mesin cetak pelet MKS-PLT15 yang telah dilakukan dengan beban operasi 25\%, 50\%, 75\% dan $100 \%$. Konsumsi listrik yang terkecil adalah ketika pengoperasian mesin pelet beroperasi dengan kapasitas produksi $25 \%$ atau 7,629 $\mathrm{Wh} / \mathrm{kg}$ setara Rp 11,021/kg. sedangkan konsumsi listrik tertinggi ketika mesin pelet bekerja pada kapasitas produksi $75 \%$ yaitu $12,35 \mathrm{Wh} / \mathrm{kg}$ atau sebesar $\mathrm{Rp} 17,842 / \mathrm{kg}$. dari penelitian yang telah dilakukan, maka direkomendasikan agar hemat listrik mesin pelet MKS-PLT15 beroperasi dikapasitas produksi kurang dari $50 \%$.

\section{UCAPAN TERIMA KASIH}

Terimakasih Kepada Lembaga Penelitian dan Pengabdian Masyarakat (LPPM) Universitas Bengkulu melalui dana Daftar Isian Pelaksanaan Anggaran (DIPA), dengan nomor kontrak 1852/UN30.15/PG/2021.

\section{REFERENSI}

[1] Kushartono B, "Pengendalian Jasad Pengganggu Bahan Pakan Ternak Selama Penyimpanan," In Prosiding Lokakarya Fungsional Non Peneliti.Pusat Penelitian Dan Pengembangan Peternakan, 1996, Pp. 94-97, [Online]. Available: Https://Www.Academia.Edu/6371003/Pe ngendalian_Jasad_Pengganggu_Bahan_Pa kan_Ternak_Selama_Penyimpanan.

[2] D. Wigati, "No Title," Institut Pertanian Bogor, 2009.

[3] National Research Council, Nutrient Requirements of Warmwater Fishes. Washington, Dc: The National Academies Press, 1977.

[4] M. G. K, Kordi ; H, Meramu Pakan Untuk Ikan Karnivora. Semarang: Aneka Ilmu, 2007.

[5] S.; W. Jaelani, Achmad ;Dharmawati, "Pengaruh Tumpukan Dan Lama Masa Simpan Pakan Pelet Terhadap Kualitas Fisik," Ziraa'ah, Vol. 41, No. 2, Pp. 261268, 2016.

[6] W. . Dozier, Pelet Quality For Most Economical Poultry Meat, 52nd Ed. J. Feed Int, 2001.

[7] R. Ginting, Penjadwalan Mesin. Yogya Karta: Graha Ilmu, 2009.

[8] Pt. Bahagia Jaya Sejahtera, "Laporan Hasil Pengujian Mesin Pencetak Pelet Merek Beje-Uptk 081 B," Cianjur- Jawa Barat, 2 017.

[9] F. Yelli, "Rancang Bangun Poros, Pencetak Dan Mata Pisau Pada Mesin Pencetak Pelet," Universitas Negeri 
Padang, 2021.

[10] M. Dani, Rahmat; Pratama, Rendy; Kuncoro, "Rancang Bangun Mesin Pencetak Pelet Pakan Ternak Sapi," Politeknik Manufaktur Negeri Bangka
Belitung, 2021.

[11] I. Harahap; Ardiansyah, "Rancang Bangun Mesin Pelet Apung Skala Peternak Kecil," Universitas Medan Area, 2019. 